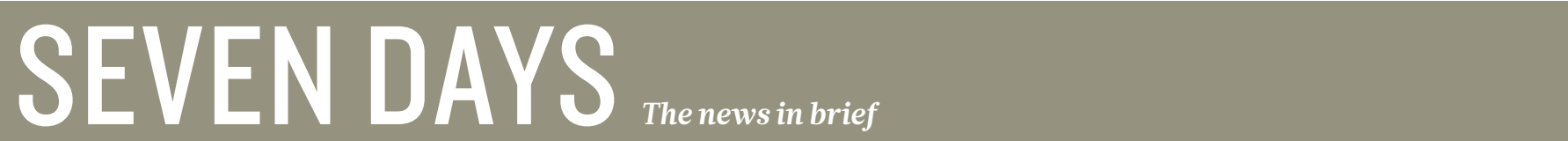

EVENTS

\section{Turkey in turmoil}

The clampdown on political opposition by Turkish President Recep Tayyip Erdoğan in the wake of the failed military coup on 15 July spread to the education sector last week. The Turkish Council of Higher Education (YÖK) told all 1,577 of the country's university deans to resign their posts, and placed a temporary international-travel ban on Turkish scholars (see Nature http://doi.org/bm4d; 2016). Erdoğan has also closed 15 universities that he alleges are closely tied to the Gülen religious movement, which he considers to be behind the coup. Several academic organizations in Europe, including the German Rectors' Conference and the European Federation of Academies of Science and Humanities, have condemned the attack on academic independence.

\section{SciDev.Net cuts}

SciDev.Net, a science and technology news service for the developing world, announced on 22 July that it is shedding about $80 \%$ of its London-based staff, including much of the editorial team, owing to a lack of funding. SciDev.Net was launched in 2001 with funding from the international development agencies of Britain, Sweden and Canada, and with guidance from journals including Nature. It said that its decision to scale down its London operations reflected a commitment to preserve its regional services.

\section{EU collaboration}

University leaders from across Europe published a joint statement on 22 July calling for continent-wide collaboration to continue in the wake of the United Kingdom's vote to leave the European Union

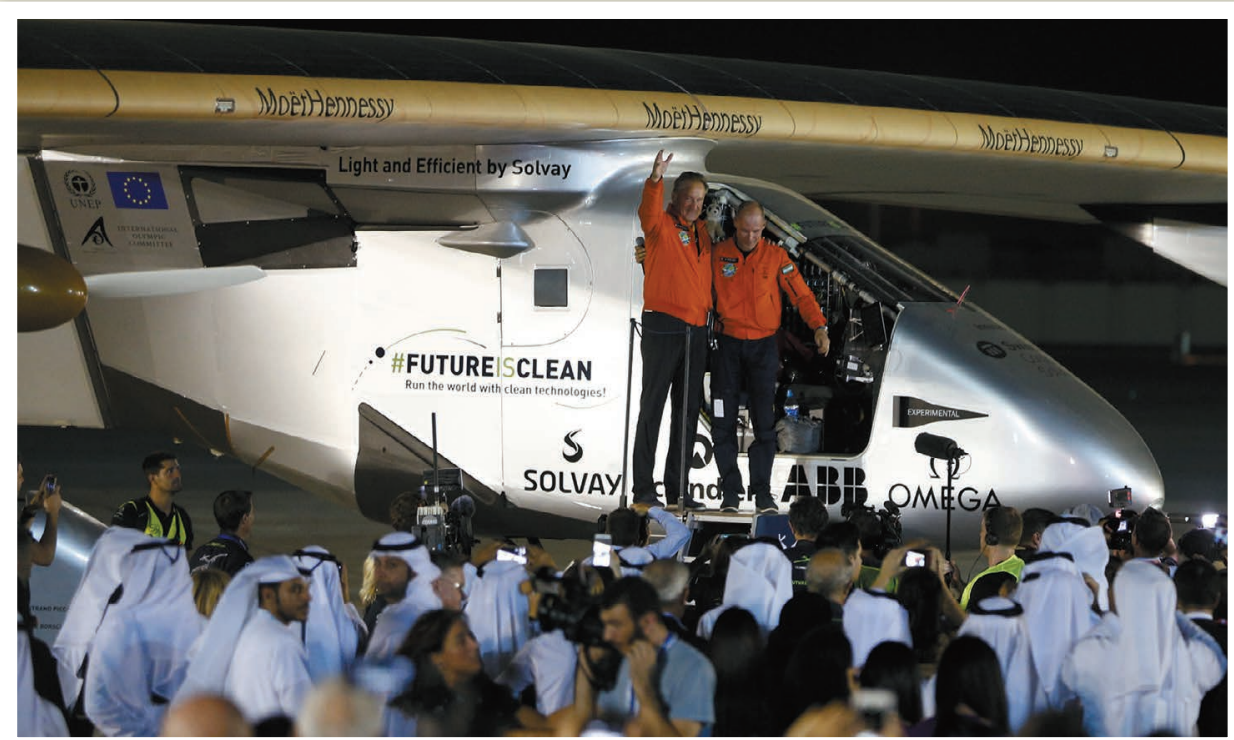

\section{Solar plane achieves historic global flight}

The world's first fuel-free flight around the world, in a solar-powered aeroplane, concluded successfully on 26 July, when the Solar Impulse 2 craft landed in Abu Dhabi. Pilots Bertrand Piccard and André Borschberg flew 40,000 kilometres in 17 separate flights over 16 months. Among the records set during the circumnavigation was Borschberg's 118-hour stretch of solo endurance flying between Nagoya, Japan, and Hawaii. Solar Impulse took off from Cairo on 24 July for the final leg, and endured turbulence over the Saudi desert before touching down with Piccard at the controls. The craft has 17,000 solar cells and a wingspan of 72 metres. last month. The statement, signed by representatives from 24 national and international university consortia, calls for the exchange of ideas and people, as well as the pooling of infrastructure, data and expertise, to continue as part of the United Kingdom's new relationship with the rest of Europe.

\section{Digital free speech}

The Electronic Frontier Foundation (EFF), a group that fights for civil liberties in the digital space, has sued the US government over a law that it says restricts researchers' ability to conduct IT science. It says that parts of the Digital Millennium Copyright Act that restrict access to computer code violate the first amendment to the US Constitution, which guarantees freedom of speech. In particular, the law "stymies creators, academics, inventors, and researchers", says the EFF, which filed the lawsuit on 21 July. Among those bringing the suit is Matthew Green, an IT-security researcher at Johns Hopkins University in Baltimore, Maryland, who says that the law blocks the work of scientists such as him who want to probe the security of digital systems.

\section{Olive-tree deaths}

The European Commission sent Italy a stern warning on 22 July, telling it to fully implement plans to stop the bacterium Xylella fastidiosa - currently devastating olive groves in the Puglia region - from spreading to other parts of Italy and Europe. In May, the commission and the Italian government agreed a containment plan that includes controversial measures such as felling infected trees and nearby healthy ones, but the commission says that the plan is not being put fully into practice. It argues that $X$. fastidiosa is one of the world's most dangerous plant bacteria, and its spread would have a huge economic impact.

RESEARCH

\section{Still in the dark}

The most sensitive experiment yet designed to catch particles of dark matter particles has concluded its 
을 search empty handed. After 줏 a 20-month run, the Large

Underground Xenon (LUX)

experiment in South Dakota announced on 21 July that it had seen no collisions of

'weakly interacting massive particles' (WIMPs) with its 370 kilograms of liquid xenon. The researchers say that WIMPs could still exist, but might interact more rarely than current experiments can detect. Preparations are under way to build a much larger dark-matter detector, called LZ.

\section{Hottest year}

This year is on track to beat 2015 as the warmest year since systematic measurements began. The first 6 months of the year were $0.2^{\circ} \mathrm{C}$ warmer than the first half of 2015, the World Meteorological Organization said on 21 July. The average global temperature was $1.3^{\circ} \mathrm{C}$ above pre-industrial levels, and $1.05^{\circ} \mathrm{C}$ above the twentieth-century average, according to data sets maintained by NASA, the US National Oceanic and Atmospheric Administration and the UK Met Office. A strong 2015-16 El Niño warming event in the Pacific Ocean contributed to the record temperatures, which are driven by rising atmospheric concentrations of greenhouse gases.

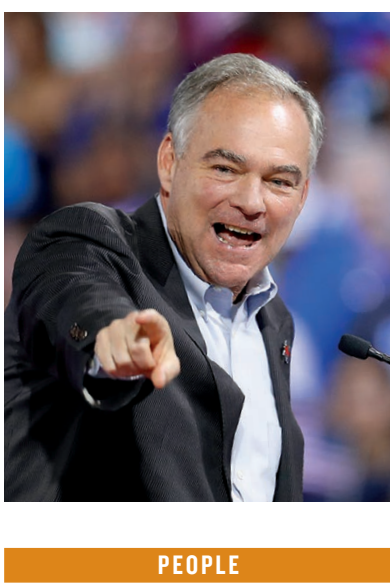

\section{Clinton picks Kaine}

Hillary Clinton, the presumptive Democratic nominee for US president, named Virginia senator Tim Kaine (pictured) as her vice-presidential running mate on 22 July. Kaine previously served as governor of Virginia, which has been among the key battleground states in recent elections. He advocated for action on climate change as governor and had worked on education and foreign policy in the Senate.

\section{Agriculture chief}

French President François Hollande ignored scientists' furious protests about his choice to head the French National Institute for Agricultural Research (INRA) for the next four years, and allowed his cabinet to confirm the appointment of Philippe Mauguin on 19 July. Mauguin, a former chief of staff to the agriculture minister, takes over "in a climate of strong mistrust", says the INRA branch of the trade union CGT. It fears that Mauguin will focus on innovation at the expense of basic research, which would be potentially "deadly" for the agency's position as a leader in agricultural research.

\section{POLICY \\ Porpoise protection}

Environmental groups have welcomed the latest attempts by Mexico's National Commission of Aquaculture and Fishing (Conapesca) to save the vaquita porpoise (Phocoena sinus), the world's most endangered marine mammal. On 19 July, Conapesca announced rules banning 'gill nets' and night fishing in the northern part of the Gulf of California, where the animals live. Only 60 vaquita were thought to have been alive in the gulf in December 2015, down from 97 in 2014; gill nets are blamed for much of the decline.

\section{Aircraft emissions}

The US Environmental Protection Agency (EPA) paved the way for new climate

\section{TREND WATCH}

Deaths from HIV/AIDS have declined steadily around the world over the past decade - but the annual rate of new infections has stayed much the same, a global data analysis published on 19 July shows (H. Wang et al. Lancet HIV http://doi.org/ bm2p; 2016). The number of new HIV infections peaked at 3.3 million in 1997, and dropped by an average of about $2.7 \%$ each year to around 2.5 million in 2005. But the infection rate has stagnated since then. In 74 countries, it has increased.

\section{DECLINE IN NEW HIV INFECTIONS STALLS}

Although deaths from HIV/AIDS have dropped steadily over the past ten years, the global annual number of new infections has stayed largely the same.

- New infections - Deaths from HIV/AIDS

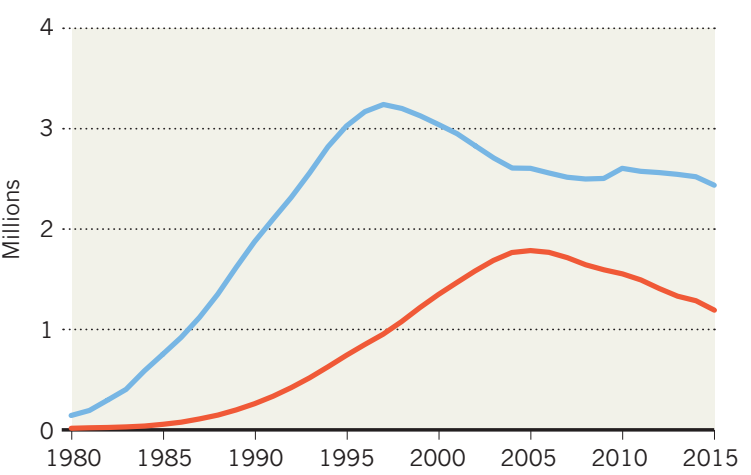

COMING UP

27 JULY-10 AUGUST

Young scientists from around the world take part in the London International Youth Science Forum 2016, hosted by Imperial College London. www.liysf.org.uk

1-12 AUGUST

Physicists discuss LIGO's gravitationalwave detection at the Kavli Institute for Theoretical Physics in Santa Barbara,

California.

go.nature.com/2afhjwa

regulations on 25 July by declaring that greenhousegas emissions from aircraft endanger public health and the environment. The finding comes five months after the United Nations' International Civil Aviation Organization (ICAO) proposed the first greenhouse-gas standards for aircraft. Environmentalists criticized the ICAO proposal as weak and are pressuring the EPA to suggest stronger regulations. The EPA said that its standards would be "at least as stringent" as those proposed by the ICAO.

\section{Predator plan}

New Zealand hopes to be free of introduced predators - which include rats, stoats and possums - by 2050, according to a plan announced on 25 July. The government will invest an initial NZ\$28 million (US\$20 million) and work with the private sector to rid the country of the predators, which it says kill 25 million native birds each year. Conservation minister Maggie Barry says that the plan will need technology that does not yet exist. 